\title{
Leprosy Survey in the British Solomon Islands, Western Pacific
}

A summarised account of the reork and results.

J. Ross Innes.

A systematic leprosy survey was carried out by the author between the dates 31st. August, 1937, and 5th March, 1938, in the British Solomon Islands Protectorate. This comprises a group of islands with a population of 94,000 people, mainly of Melanesian race, and a few Chinese and Europeans. Nearly a quarter of the total population was examined in repeated journeys and continued residence amongst the people. The only forms of transport were by small schooners, or foot along native tracks.

(1) Main Methols of the Survey.

In each island, large or small, either the whole population was attracted for survey in the various centres or good representative samples were obtained. It was found not practicable to use treatment of leprosy as an attracting force: instead, treatment of yaws was often used, for even the bush natives knew the value of yaws injections, and assembled in full numbers whenever it was notified to them that injections were to be given. In addition, the very simple but effective 
scheme was followed of rewarding lepers and those who brought them, with sticks of tobacco, also headmen who turned the people out well. Finally, the influence of government district officers was always of great value: the natives readily responded to their propaganda and preparation of the field. The result of all this was that'men, women, and children invariably came for examination in fine numbers. The physical examination was usually of naked or almost naked people, and to careful inspection and palpation was added the specific tests for (listurbance of sensation and the examination of specimens microscopically. ()bvious (liseases were noted for each person examined, whether a case of leprosy or not. By resicling in each island, it was possil)le to study the people, their mental attitucle, folklore, diet and ways of living.

(2) Leprosy Survey, British Solomon islanis. Table of Main Essential Data anil Resilits.

ABLE

NAME
OF MAIN
ISLANIJO
IDISTRIC

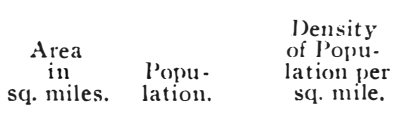

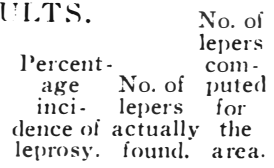

ISI.ANI) OF

MALAITA $\ldots$

$1,450 \quad 40,000$

27

10,245

1.347

$138 \quad 600$

ISLANI) OF

NGGELA $\quad \ldots$

$235 \quad 5,300$

24

1,410

$0.992 \quad 14$

40

ISLANI) OF

GUAI)AL-

CANAL

ISLANI) OF

$\begin{array}{lll}\text { YSABEL } \quad \ldots & 1,802\end{array}$

$2,500 \quad 14,880$

5 to) 6

5,023

0.89

44

120

RUSSELL

ISLANI)S $\ldots$
ISLANI) $($ F

SAVO)

70

$4,200 \quad 2$ to 3

$2,717 \quad 0.552$

15

25

I. OF SAN

CRISTOVAL

Total figures for

whole B.S.I P.

Notes.-Along with the above Table, it is advisable to study the general map of the Protectorate.

The figures for the Island of Nggela include those of the capital of the Protectorate, Tulagi. In this place, besides natives, 76 Chinese residents were examined: there was no case of leprosy amongst the Chinese, though a case had been diagnosed and had died a few years before.

Of the main areas not visited by me, there is other evidence that there are no lepers on Choiseul, and in New Georgia and other north western islands from earlier available data and the trend of the present survey results, 1 think it is very probable that they have an incidence 
of leprosy of between 0.5 and $0.6 \%$. In the outlying islands, such as Lord Howe and Remnell and Santa Cruz, there is apparently not much fear of leprosy outbreaks, nor knowledge of it.

The islands inclucled in the survey being all the important ones, sufficient information was gained to assess the leprosy problem and to work out a plan of control.

\section{(3) The Distribution of Leprosy.}

Points of interest are (a) the preponderance of leprosy in the Island of Malaita: (b) the marked tendency for the disease to be of heavier incidence in bush than coastal dwellers: (c) the striking fact that density of population in small islands did not necessarily imply a high incidence, as in the Island of Savo in the Table given, the small islands of Santa Anna and Santa Catalina off San Cristoval, and the large number of artificial islands off the Malaita coast: (d) leprosy is distributed as a small group or family discase, there being no roads and nothing of modern intercommunication among the people: (e) leprosy in the Solomons has been found to be most heavy in the primitive, and to lessen in incidence with degree of successful sophistication or civilization of the natives.

\section{IJISCUSSION OF THE ABOVE POINTS.}

Malaita leads the list in leprosy incidence. It has the heaviest population, and enquiries into folklore and tradition gave distinct evidence that the disease has been indigenous a very long time, and it is even possible that the original fount and focus of the Protectorate's leprosy is Malaita. The people are still largely savage and semisavage, and it was in this island that the striking preponderance of leprosy amongst the bush or inland dwellers first emerged. Even in spite of the overcrowding on the coastal islands, very little leprosy was found on the coast. I think the explanation must be that not only are the coastal dwellers more cleanly and have a better diet, and more intelligence and adaptability, but that the real home of leprosy is in the bush, and that when these coast people long ago escaped to the coast from the bush, they escaped to a larger life, and removed themselves from proximity to the leprosy foci of the island. One may imagine that leprosy was long ago brought to the island by the original invasion of Indo-Melanesians, people who first domiciled themselves in the bush. Now it happens that not all the islands are alike. They have varying degrees of bush versus coastal inhabitance. Yet in all the same definite tendency can be traced, that is, that leprosy is or was a bush disease. The island of Guadalcanal is in a stage further on of the modern movement to civilize, and to have more people living back on the coast again. The survey here revealed a less incidence of leprosy than in Malaita, and an expedition to obtain a pure bush sample revealed a greater bush incidence once more, namely, $1.43 \%$ against coastal $0.67 \%$.

Consider now the Island of Ysabel. In this, the process of civilizing and of migration back to coastal domicile has gone much further 
than in Malaita or (iuadalcanal, so that there are 1,400 bush people in 20 villages, and 2,800 coastal people in 37 villages. The survey found an incidence of $0.43 \%$ bush and 0.59 coastal leprosy. For the first time it seemed as if the bush preclominance was lost, but on the discovery that many of these coastal lepers had had in their youth a bush domicile, it was seen that the survey if done some 15 or 20 years ago would have found the true bush predominance.

\section{(4) The Disease Itself.}

The clinical appearance of leprosy in the Solomons, bearing in mind the differences of skin colour and texture, were much the same as what the author was accustomed to in Inclia. The clisease bore all the marks of a long domiciled leprosy of moderate incilence, manifestations, and rate of increase. There was no eviclence suggesting any clanger of an explosive outbreak anywhere in the Solomons: on the contrary, in some islands, e.g., Ysabel and Guadalcanal, there is some eviclence of decrease. Of the 121 cases of leprosy studiecl, about one half were infectious, and of all cases the predominating type was Neural. There was found to be an unusually large number of child contacts living in close association with lepers.

(5) Preidsposing Factors.

(a) The attitude of the people to leprosy. The native explanation of leprosy is usually a smiting by spirits. There is some glimpse of the idea of its contagion, but in practice nothing is done to segregate, unless in peoples under the propaganda of government officers. There is no understanding of the danger of children living in close contact, and propaganda should be extended to this point. There is not much of social ostracism of lepers, and there is no trace of murcler of lepers by the community.

(b) Lack of personal cleanliness is more marked in bush people, but in most inhabitants the spread of the use of bathing with soap and fresh water is called for.

(c) Deficient diet is a definite problem, for the native diet being mainly root vegetarian, there is a great lack of first class biological protein in many cases. The modern foods introduced have been tinned meats, biscuits, and rice: these are not available to the bushman to any extent, and only to the wealthy on the coast. The introduction of the use of wheat, and the foundation of a milk supply and demand are likely to be of great public health and anti-leprosy value. Goats may be found more suitable than cows. Coastal dwellers have much more fresh fish in their diet than the bushmen: apparently it benefits them greatly. 
(d) Lack of roads and lack of a widespread system of schools.

Without these propaganda in public health and the best work in civilization are held up, which predisposes to the persistence of the bush foci of leprosy. The dietary improvements and the subjugation of concomitant diseases also are held up for lack of roads and schools.

(e) Predisposing discases.

In the examination of 21,615 inhabitants, the plan of recording the more obvious prevalent diseases gave the following incidences :-

\begin{tabular}{|c|c|c|c|c|c|c|}
\hline \multicolumn{3}{|c|}{ Enlarged malarial spleen } & & & $\ldots$ & $70 \%$ \\
\hline Yaws & $\ldots$ & $\ldots$ & $\ldots$ & .. & $\ldots$ & $54 \%$ \\
\hline $\begin{array}{l}\text { Skin diseases, } \\
\text { prevalence of }\end{array}$ & & & $n$ & .. & ing & $27 \%$ \\
\hline Eye diseases & $\ldots$ & $\ldots$ & $\cdots$ & .. & $\cdots$ & $5 \%$ \\
\hline Tropical ulcer & $\ldots$ & $\ldots$ & $\ldots$ & .. & - & $2 \%$ \\
\hline Tuberculosis & $\ldots$ & $\ldots$ & $\cdots$ & .. & $\ldots$ & $1 \%$ \\
\hline Filariasis & $\ldots$ & $\ldots$ & $\ldots$ & .. & $\ldots$ & $2 \%$ \\
\hline Infantile paraly & & $\cdots$ & $\ldots$ & .. & $\ldots$ & $0.4 \%$ \\
\hline Rickets $\ldots$ & $\ldots$ & $\ldots$ & ... & .. & $\ldots$ & $\%$ \\
\hline
\end{tabular}

Many other diseases were noted, but for brevity the ones consolidated above will suffice. It is evident that the dominant trinity is malaria, yaws, and skin diseases: and it is very likely that they must be regarded as the chief predisposing diseases to leprosy. In the cases of yaws and skin diseases we also have the chief confusions in the diagnosis of leprosy in the islands.

(6) Outline of the Problem in Leprosy and its Solution.

We have 94,000 people of varying types, temperaments, and degrees of intelligence scattered at 6 to 7 per square mile over these many islands of the Solomons. Fortunately there seems to be a well-marked common racial inheritance, and there is a central Protectorate Government which can coordinate all efforts to improve the leprosy situation. Sea divides island from island, and if necessary each island could be cleaned up in turn. The incidence of leprosy is moderate, and the increase at a slow normal rate. The people respond to civilizing influences well, and likewise does the leprosy incidence. The centre of the problem is Malaita, with its heavy population and heaviest incidence, and its being 
perhaps the least civilized. It seems to me that the lines of aclvance must be on the paths of :--

Roa(ls, schools and propaganda, dietary and agricultural studies and improvements, instruction in hygiene, the use of soap, making soap more available.

Provision of adequate sea transport for the leprosy campain in the shape of a fast seaworthy modern schooner with reliable engines.

Founding of a leprosy scheme to include a special medical officer, a central clearing station for lepers from all islands, a leper colony on the Island of Ysabel on the voluntary principle with full provision for occupation of the patients in farming or inclustry, and for the care of children of leprous parents.

(It may be found more convenient to the needs of the Protectorate to appoint a medical officer of health including leprosy, because of the linkage with malaria, yaws, and public health. The existing yaws campaign might thus be expanded to include leprosy and public health.)

The valuable mission medical work on some of the islands and their schools would no doubt be found easily to fit into the anti-leprosy scheme, likewise the persuasive influence of district officers and of native medical practitioners under government. The latter would be trained in leprosy at the Colony.

If possible, it would be of the greatest value if a European lay worker were obtained for the Colony, as so much of a practical nature needs to be worked out in housing, agriculture, industries, and the like.

\section{ACKNOWLEDGMENTS.}

I am grateful to Dr. Ernest Muir, C.I.E., who suggested that I do this survey: to His Honour the Resident Commissioner, F. N. Ashley, Esq., C.M.G., and to Dr. H. B. Hetherington, Senior Medical Officer, for continued assistance and advice during my stay in the Protectorate: to all District (Officers and other government officials who helped on the progress of the work: to missionaries and planters who gave generous assistance: to Dr. Clifford James of Fauabu who gave in his area valued help and information: to Mr. A. N. A. Waddell who drew maps and to a great number of friendly natives, police, and boats' crews who made life possible. I wish also to express my admiration for the work and usefulness of the native medical practitioners with whom I had the privilege of co-operating in the survey. 